\title{
FOREIGN DIRECT INVESTMENT AND ECONOMIC GROWTH: TAKING STOCK OF THE CURRENT STATE OF EMPIRICAL RESEARCH
}

\author{
Darko Horvatin ${ }^{17}$
}

UDC / UDK: 339.727.22:330.35:303.025

JEL classification / JEL klasifikacija: O47, F21

DOI: https://doi.org/10.22598/pi-be/2019.13.2.179

Scientific review / Pregledni znanstveni rad

Received / Primljeno: July 20, 2019 / 20. srpnja 2019.

Accepted for publishing / Prihvaćeno za tisak: November 20, 2019 / 20. studenog 2019.

\section{Summary}

Taking into account theory of foreign direct investment (FDI) with neoclassical and endogenous theories of economic growth, FDI has been identified as a factor which directly (capital accumulation) and indirectly (technology transfer) positively influences economic growth. However, empirical findings regarding this matter are quite diverse. Hence, the purpose of the paper is to take a critical view of the current state of empirical research regarding the impact of FDI on the recipient country's economic growth. In doing so, this research will inevitably take a view of the total global FDI inflows from 1970 until present time. The general finding is that there exists no unanimous conclusion as to the impact of capital inflow on the host country's economic growth due to a variety of reasons sometimes not properly treated within the empirical analytical models. More specifically, this impact varies from being very positive to neutral, at best, or even negative. The reasons for such ambiguous findings arise from analytical weaknesses (the way in which analytical samples are created) and the lack of better understanding of theoretical and empirical aspects of the contribution of foreign capital to the host country's economic growth (no differentiation between short-and long-term effects).

Key words: FDI, economic growth, greenfield investment, mergers and acquisition.

17 Darko Horvatin, PhD, President of the Management Board, Croatian Pension Investment Company, Zagreb, Croatia, E-mail: darko.horvatin@hmid.hr 


\section{INTRODUCTION}

Economic growth represents an undisputed economic phenomenon and an ultimate policy objective, irrespective of the prevailing economic doctrine. It makes possible for nations to achieve higher level of development and for individuals to improve their economic status on a sustainable manner. As such, economic growth is usually modelled as a result of the interaction of labour, capital, and technology. For countries scarce in their own capital and savings, FDI comes as a valuable resource in securing economic growth, yet without creating additional debt burden. In this context, FDI has a multiplying effect on economic growth. On one hand the inflow of foreign capital increases local capital base and employment, while on the other it ensures transfer of modern technology and know-how, and improves local labour skills, what can be ultimately identified in higher productivity growth. At the company level, FDI shows an immediate effect on business performance (direct short-term effects), while later it creates the spillover effects, which spread across sectors and time spans. These effects can be identified in the improved productivity level, as well as in the general efficiency of the economy (indirect long-term effects).

In the recent two decades cross-border capital flows became an important source of capital for the developing and emerging economies. In 1990 FDI inflow on global scale reached 207 bn USD, while in 2018 it went beyond 1.500 bn USD (UNCTAD, 2019). The peak in global FDI flows was realized in 2007, when international capital flows reached 2.002 bn USD. These figures suggest that FDI is an important factor in the global economy. Since 2011, more than half of the global FDI flows has been realized in the developing countries ${ }^{18}$ where the profitability of investment is estimated at about $8,4 \%$, while that of the developed countries ranged slightly below $5 \%{ }^{19}$. As far as foreign capital is concerned, two thirds of global FDI flows was realized in form of greenfield investment, while the remaining one third took the form of mergers and acquisitions (M\&A).

Most of empirical researches use total amount of FDI in analysis while ignoring the fact that greenfield FDI and M\&A are two different types of investments by their nature and as such it is hardly to believe that both will have identical influence of economic growth. As the former involves mainly new capital assets, the latter is just a transfer of ownership on existing ones, greenfield would seem more likely to affect growth via increased physical investment, while M\&A would be more likely to do so via enhanced

18 According to the UNCTAD World Investment Report 2019, the top 5 FDI recipient countries in 2018 were USA, China, Hong Kong, Singapore and Netherlands.

${ }^{19}$ UNCTAD World Investment Report 2013. 
productivity growth (Calderón et al., 2004). The lack of distinction between greenfield FDI and M\&A could result in distorted picture of FDI influence on growth.

The paper consists of four parts. After the introduction, the second part presents the main theoretical aspects of FDI and economic growth. The third part gives a thorough critical overview of the main findings of the empirical research about the impact of FDI on economic growth, and identifies the main weaknesses and shortcomings of these studies. Finally, part four is reserved for conclusion and discussion.

\section{MAIN THEORETICAL ASPECTS OF FDI AND ECONOMIC GROWTH}

$\mathrm{FDI}^{20}$ refers to an investment made to acquire lasting interest in enterprises operating outside of the economy of the investor. Further, in cases of FDI, the investor's purpose is to gain an effective voice in the management of the enterprise. The foreign entity or a group of associated entities that makes the investment is termed the "direct investor". The unincorporated or incorporated enterprise's branch or subsidiary, respectively, in which direct investment is made is referred to as a "direct investment enterprise". Some degree of equity ownership is almost always considered to be associated with an effective voice in the management of an enterprise; IMF and OECD suggest a threshold of 10 per cent of equity ownership to qualify an investor as a foreign direct investor. An effective voice in management only implies that direct investors are able to influence the management of an enterprise and does not imply that they have absolute control. The most important characteristic of FDI, which distinguishes it from foreign portfolio investment, is that it is undertaken with the intention of exercising control over an enterprise.

Once a direct investment enterprise has been identified, it is necessary to define which capital flows between the enterprise and entities in other economies should be classified as FDI. Since the main feature of FDI is taken to be the lasting interest of a direct investor in an enterprise, only capital that is provided by the direct investor either directly or through other enterprises related to the investor should be classified as FDI. The forms of investment by the direct investor which are classified as FDI are equity capital, the reinvestment of earnings and the provision of long-term and short-term intracompany loans (between parent and affiliate enterprises).

Foreign investment can be divided (Julius, 1991) into:

${ }^{20}$ Definitions of FDI are contained in the Balance of Payments Manual: Fifth Edition (BPM5) (Washington, D.C., International Monetary Fund, 1993) and the Detailed Benchmark Definition of Foreign Direct Investment: Third Edition (BD3) (Paris, Organisation for Economic Co-operation and Development, 1996). 
1. Portfolio investment - which means acquiring securities up to $10 \%$ of voting rights in a foreign company. Investment horizon in this case is a short term, and investor's motive is an increase in the securities market value;

2. Foreign direct investment - incorporate acquiring at least $10 \%$ of voting rights in a foreign company with a long term investment horizon. In doing so investor's motive is to participate in control and management of the company with and active role in creation and realisation of the company's business policy. Further, FDI can be divided into:

2.1. Greenfield investment - which means setting up a new company abroad. For the host economy it means: an increase in capital base, new jobs and technology transfer;

2.2. Brownfield investment - usually means acquiring of the existing companies abroad, followed by wide restructuring, which sometimes incorporates negative short term effects in form of layoffs and a decrease in output. In most cases it is linked to privatization projects, as it was the case with the European transitional countries during the 1990's. Received capital is often used for government spending and covering of public deficits, instead of being directed to new investments;

2.3. mergers and acquisition - are related to a process in which a foreign company merges with, or take over the control over local company in order to acquire some strategic asset in that way (technology, licence, market share, etc.). M\&A generally take place between developed countries with sound business environment and efficient capital markets.

It is generally considered that foreign direct investment represents an important means of economic growth and development for all countries and for developing economies in particular. Nowadays, FDI is considered to be the primary form of international capital flows in the global economy and as such, have a strong impact on the economies of recipient countries. From the standpoint of host economy, FDI is considered as an acceptable source of international capital and technology. Moreover, for less developed countries FDI is a way to participate in the global production chain. In the case of countries with a low level of capital, FDI is often the main source of capital necessary for sustainable development. The impact on the domestic economy, however, is not always the same because it is subject to various factors such as the level of development and resource availability. New technologies have an important role in the modern world, especially in the context of economic growth. The economies of smaller countries and less industrialized regions are trying to attract foreign investment and thus participate in the global production chain. 
Analysis of FDI influence on host country is relevant because of its importance on total economy, which is in most cases reflected through: inflow of fresh capital, technological and organisational improvement of production process, stronger competitive pressure on local companies, employment increase and improvement of working skills, productivity increase, export growth, positive influence on balance of payment, increase of tax revenues, macroeconomic stability, integration of local economy into global economic flows.

\subsection{Theories of FDI}

There is no unique theory that can explain the phenomenon of FDI. Multidisciplinary view on economy, international business, organization and management is needed, while seeking to an answer to the question of what causes and drives foreign direct investment. The theory of international trade cannot explain the emergence of multinational companies because of its focus on international trade and not on setting up a business abroad. Therefore, the theory of FDI can be viewed from different perspectives, while there is some overlap of factors referred to in some theories, or spread across a number of different theories. According to Nayak and Choudhury (2014) FDI theories can be divided into:

1. theories of FDI based on perfect competition;

2. theories of FDI based on imperfect markets;

2.1. industrial organization approach;

2.2. FDI based on monopolistic power;

2.3. internalization theory of FDI;

2.4. oligopolistic theory explaining FDI;

2.5. eclectic Paradigm to FDI;

3. FDI theory based on strength of currency;

4. FDI theories related international trade;

5. linkages between FDI and regional integration agreements;

6. FDI theories explaining investment from developing countries.

This paper will not go deeper into the explanation of all FDI theories. The emphasis will be put on theories based on imperfect markets, especially on ownership and monopolistic power theories as they are complementary to endogenous model of economic growth, which recognises technological progress as a key element for sustained economic growth. The essence of industrial organization approach (Hymer, 1960, 1976) is that companies operating abroad have to compete with local companies that have advantage in terms of culture, language, knowledge of legal system and consumer preferences. These disadvantages have to be offset by some form of market power of 
investing company in order to make investment abroad profitable. The source of market power come in form of patent-protected superior technology, brand names, marketing and management skills, economies of scale and cheaper source of finance. Hymer considered technological superiority as the most important advantage, while Kindleberger (1969) extended the work of Hymer and put forward his theory of FDI on the basis of monopolistic power. According to this theory, specific advantage appears in form of superior technology, managerial expertise, patents etc. Such advantages generally encourage company to invest abroad in order to economically fully exploit them, instead of having them shared with potential competitors in the foreign market. The bigger the chance of earning monopoly profits, the higher will be the motive among companies to invest directly abroad.

Buckley and Casson (1976) explained FDI by stressing the role of intermediate inputs and technology in a theory known as internalization theory. According to it a company engaged in research and development may develop a new technology or process. Instead of selling it to competitors, company may choose to internalize it within the same organization by using the backward and forward linkages. If the process of internalization involves business operations in different countries, then the resulting effect can be summarized as the FDI.

Oligopolistic theory explaining FDI (Knickerbocker, 1973) differentiates between two main motives of a company when choosing a country as a potential location for setting up a new facility. On one hand, a company may seek to improve market access of the FDI host country (Derado, 2013), while on the other company may want to utilize the relatively abundant production factors available in this country. In addition, there exists a third motive as a company may invest abroad to match the rival's (strategic) move. Under oligopolistic market conditions, companies in an industry tend to follow each other's location decision. Knickerbocker (1973) suggests that oligopolistic reaction is related to the level of concentration and decreases with product diversity. When trying to explain why companies set up a subsidiary abroad Dunning (1973, 1980, 1988) synthesized the main theoretical inferences of imperfect markets - the monopolistic and internalization theories - and added a third, location theory. According to him, a company would engage in FDI only in case when all three conditions are fulfilled:

1. company should have ownership advantage (eg. advanced technology);

2. it is beneficial to internalize these advantages (instead of marketing them to competitors);

3. there must be some location advantages to use ownership advantages in foreign location (abundance with production factors - raw materials, cheap labour force, country is member of regional integrations, etc.). 
Ownership advantages appearing in the form of tangible and intangible assets (patents, technical knowledge, management skills, and superior technology) are specific to a certain company and may be enjoyed over local and foreign competitors. It is more beneficial to internalize production as it is more profitable then to depend on external markets. Location advantages of different countries have an important role in final decision which country will become host to the activities of multinational corporations (access to protected market, lower production costs, lower political, legal and cultural risk).

\subsection{Theory of economic growth}

Economists have always tried to understand and explain the sources of economic growth in order to help policymakers create an optimal macroeconomic framework which would make possible GDP growth and full employment in a sustainable manner. All theories and models of economic growth recognize three key elements - capital, labour and technical progress. Result of their interaction is long term sustainable economic growth.

It is generally considered that modern theory of economic growth began with the neoclassical model, formulated by Solow (1956). He was one of the first economists who developed growth model which made distinction between old and new capital. According to Solow, the new capital is more valuable as it is produced by modern technology. Hence, it will be more productive than the old one. Solow considered that capital, labour and technology are main contributors to the long term economic growth. According to him, growth is primarily explained by the accumulation of physical capital and labour, with diminishing returns on invested capital. All other growth which cannot be attributed to these factors is assigned to "technological progress". The sources of technological progress are not explained by the neoclassical growth model - therefore, it is called unexplained or exogenous technological progress. It is also known as "Solow residual" or "Total factor productivity".

In the 1980-ies, several new economic growth models appeared that tried to explain technological progress, which are known as endogenous growth models. In the first group of endogenous models (Romer, 1986; Scott, 1991; Aghion and Howitt, 1992, Lucas, 1993) growth is induced by externalities where one company creates new knowledge what has positive external effect on production possibilities of other companies as knowledge, according to this model, cannot be perfectly protected by patent or stayed secret. The main representative of the endogenous growth theory is Romer whose growth model is based on innovation. His theory suggests that innovation in the economy creates new products and technology, which in turn will impact on aggregate productivity growth throughout the economy. The authors that represent the second group of endogenous 
models (Romer, 1990; Grossman and Helpman 1990; King and Rebelo, 1990, Helpman, 1992.) put more attention to research and development. In these models the rate of growth depends on the amount of resources that are intended to innovation activities R\&D), degree to which new technologies can be used privately (on the degree of monopoly power) and the time horizon of investors. Countries (or better said multinational companies) with advanced research and development bring new technology through the transition channels and through foreign direct investments in other countries. This leads to spillover effects and ultimately, through productivity growth, resulting in overall economic growth. The third group of endogenous models (Becker, Murphy and Tamura, 1990; Jones and Manuelli, 1990; King and Rebelo, 1993) put attention on constant returns on wide defined capital concept (capital includes human capital) where capital becomes the main mean of generating endogenous growth. Accumulation of physical capital will lead to accumulation of human and intellectual capital as well. In other words, AK model does not make an explicit distinction between capital accumulation and technological progress. More formally AK model is actually a neoclassical model without diminishing returns.

\subsection{Complementarity of FDI and economic growth theories}

FDI is a strong vehicle for capital accumulation and technological change. As both of these inputs are essential for economic growth, it is expected that the influence of FDI on economic growth is significant. Such investments are mostly carried out by multinationals who are leaders in R\&D and technology. Hence, FDI is seen not only as a flow of capital but also as a channel through which technology transfers between countries can take place. This potential of FDI to serve as a channel of technology transfer where technology is within endogenous growth models recognised as crucial element for long term economic growth is a main reason why it has generated a lot of interest to researchers. According to FDI theory based on monopolistic power, the company has the exclusive ownership over certain technology (resulting from investment in R\&D) and instead of selling it to foreign competitors, the company decides to enter into the foreign market either through setting up a new company (greenfield FDI) or through takeover of existing company (M\&A). Both modes of FDI entry contribute to the economic growth but on different manner and not within the same period.

There are three basic transmission channels through which FDI affects technological change, improves the physical capital stock and generates economic growth (Neuhaus, 2006). Greenfield immediately improves the physical capital stock, what, according to neoclassical model, positively affects economic growth - in short run. If such company uses a new production technology it will result in increased productivity and higher economic growth. This channel is called "direct transmission". The level of the 
impact on economic growth through ownership transfer from local to foreign company (M\&A) will depend on the amount of knowledge transfer (technology, managerial skill, know-how, marketing) from the investing foreign companies to the local ones. This is "indirect channel". In addition to these two basic transmission channels, FDI lead to second round effects. The presence of foreign companies (especially in developing countries) makes it easier for domestic companies to adopt new technologies and raise productivity through technology diffusion and knowledge spillover effects. It is called "second round transmission", happens with time lag and has a long term influence on economic growth.

Theoretically, FDI can influence economic growth in different ways. On the one hand, the neoclassical model of economic growth (Solow, 1957) suggests that FDI increases capital base and acts as a source for financing future investment projects (Brems, 1970). In such a model with diminishing returns, FDI can achieve only shortterm growth effects, what makes the difference between domestic and foreign investment irrelevant because FDI is treated just as pure capital inflow. Long-term effects could only be achieved by exogenous, unexplained technological progress. According to this model the influence from FDI on economic growth were also transitory, not permanent. But, as FDI is one of the important vehicles for technology transfer, it was believed that FDI has to contribute to technological progress and thereby to economic growth.

On the other hand, endogenous growth models recognise technology resulting from investments in research and development as the most important factor which enables productivity increase and sustainable long term economic growth. FDI is important way of technology transfer (Borensztein, De Gregorio, and Lee, 1998) from developed to developing countries, while multinational companies become their mains source. Foreign direct investments in addition to fresh capital and new investments also include transfer of managers, knowledge and skills necessary for successful implementation of modern technology with positive effect on economic growth eventually. Till the emergence of the endogenous growth models (late 1980-ies), long-term growth in economic models was not explained. Romer (1986) was the first to overcome the decreasing returns problem of the neoclassical growth models by modelling increasing returns model through knowledge and technology spillovers.

\section{CRITICAL OVERVIEW OF THE MAIN FINDINGS OF THE EMPIRICAL RESEARCH}

However, empirical findings regarding the growth effects of FDI are not so unanimous. Although most papers support the finding that FDI positively influences 
economic growth, a considerable amount of research finds these effects to be neutral, or even negative. Thus, such a divergence in results of various studies has sparked the curiosity of the reasons behind the differing conclusions.

Theory suggests that FDI may positively contribute to economic growth directly (through company that receives FDI) and indirectly (through technology and knowledge spillovers form FDI company to local companies which become more productive and more competitive). Lots of researchers tested those theoretical influences of FDI to economic growth - with varied results. The aim of this paper is by reviewing a number of empirical studies in trying to identify their weaknesses and shortcomings as a possible explanation for findings. Overview of reviewed literature is shown in tables which follow. Table 1 presents several researches on the FDI influence on economic growth on bulk sample of countries.

Table 1. Researches on FDI influence on Economic Growth - Bulk sample

\begin{tabular}{|l|l|l|l|}
\hline \multicolumn{1}{|c|}{ Sources } & \multicolumn{1}{|c|}{ Data span } & \multicolumn{1}{c|}{$\begin{array}{c}\text { Effects of FDI on } \\
\text { EG }\end{array}$} & \multicolumn{1}{c|}{$\begin{array}{c}\text { Weaknesses and } \\
\text { shortcomings }\end{array}$} \\
\hline $\begin{array}{l}\text { Adewumi } \\
(2006)\end{array}$ & $\begin{array}{l}\text { 11 African } \\
\text { countries, 1970- } \\
2003\end{array}$ & $\begin{array}{l}\text { Positive - but } \\
\text { statically } \\
\text { insignificant }\end{array}$ & $\begin{array}{l}\text { Sectorial split of FDI } \\
\text { needed to get deeper } \\
\text { insight. }\end{array}$ \\
\hline Agrawal (2011) & $\begin{array}{l}\text { India and China, } \\
1993-2009\end{array}$ & $\begin{array}{l}\text { Positive } \\
\text { Higher influence in } \\
\text { China }\end{array}$ & $\begin{array}{l}\text { No differentiation between } \\
\text { Greenfield and M\&A, no } \\
\text { time lag between FDI } \\
\text { inflow and GDP }\end{array}$ \\
\hline Alfaro (2003) & $\begin{array}{l}47 \text { countries, 1985- } \\
1999\end{array}$ & $\begin{array}{l}\text { Negative - in } \\
\text { primary sector } \\
\text { Positive - in } \\
\text { secondary sector } \\
\text { Ambiguous }- \text { in } \\
\text { tertiary sector }\end{array}$ & $\begin{array}{l}\text { Relatively short period, no } \\
\text { differentiation between } \\
\text { greenfield and M\&A, } \\
\text { heterogeneous sample }\end{array}$ \\
\hline $\begin{array}{l}\text { Alfaro et al. } \\
(2009)\end{array}$ & 72 countries & $\begin{array}{l}\text { Positive - depends } \\
\text { on absorptive } \\
\text { capacities }\end{array}$ & $\begin{array}{l}\text { Heterogeneous sample - } \\
\text { different absorptive } \\
\text { capacities, no } \\
\text { differentiations among FDI } \\
\text { types. }\end{array}$ \\
\hline $\begin{array}{l}\text { Apergis et al. } \\
(2006)\end{array}$ & $\begin{array}{l}\text { 27 countries in } \\
\text { transition, 1991- } \\
2000\end{array}$ & $\begin{array}{l}\text { Positive - at } \\
\text { countries with } \\
\text { higher GDP per } \\
\text { capita that } \\
\text { implemented }\end{array}$ & $\begin{array}{l}\text { No differentiations between } \\
\text { greenfield and M\&A, } \\
\text { include time leg }\end{array}$ \\
\hline
\end{tabular}




\begin{tabular}{|c|c|c|c|}
\hline & & $\begin{array}{l}\text { successful } \\
\text { privatization } \\
\text { programs. }\end{array}$ & \\
\hline $\begin{array}{l}\text { Beugelsdijk et } \\
\text { al. (2008) }\end{array}$ & $\begin{array}{l}44 \text { countries, } \\
1983-2003\end{array}$ & $\begin{array}{l}\text { Positive - } \\
\text { developed } \\
\text { countries. } \\
\text { Horizontal FDI - } \\
\text { stronger effect. } \\
\text { Neutral - } \\
\text { developing } \\
\text { countries }\end{array}$ & $\begin{array}{l}\text { Big sample, no } \\
\text { differentiation between } \\
\text { greenfield and M\&A }\end{array}$ \\
\hline $\begin{array}{l}\text { Carkovic and } \\
\text { Levine (2002) }\end{array}$ & $\begin{array}{l}72 \text { countries, } 1960- \\
1995\end{array}$ & Neutral & $\begin{array}{l}\text { Big sample, no } \\
\text { differentiation between } \\
\text { greenfield and M\&A }\end{array}$ \\
\hline $\begin{array}{l}\text { Curwin, } \\
\text { Mahtuga (2014) }\end{array}$ & $\begin{array}{l}25 \mathrm{CEE} \text { and ex } \\
\text { SSSR countries }\end{array}$ & Negative & $\begin{array}{l}\text { No differentiation between } \\
\text { Greenfield and M\&A, short } \\
\text { time period, no time leg }\end{array}$ \\
\hline $\begin{array}{l}\text { Darrat et al. } \\
(2005)\end{array}$ & $\begin{array}{l}\text { CEE and MENA } \\
\text { (Middle East and } \\
\text { North Africa), } \\
1972-2002\end{array}$ & $\begin{array}{l}\text { Positive - for } \\
\text { countries on the } \\
\text { path to regional } \\
\text { integrations (EU) } \\
\text { Negative }\end{array}$ & $\begin{array}{l}\text { No differentiation between } \\
\text { Greenfield and M\&A }\end{array}$ \\
\hline $\begin{array}{l}\text { Harms and } \\
\text { Meon (2011) }\end{array}$ & $\begin{array}{l}80 \text { countries, } 1987- \\
2005\end{array}$ & $\begin{array}{l}\text { Positive - } \\
\text { Greenfield } \\
\text { Negative - M\&A }\end{array}$ & $\begin{array}{l}\text { Too big and heterogeneous } \\
\text { sample, no differentiation } \\
\text { between short- and long- } \\
\text { term effects }\end{array}$ \\
\hline Hayali (2014) & $\begin{array}{l}57 \text { developing } \\
\text { countries, 1990- } \\
2010\end{array}$ & $\begin{array}{l}\text { Positive - } \\
\text { greenfield and } \\
\text { M\&A }\end{array}$ & $\begin{array}{l}\text { Short time period, big } \\
\text { sample }\end{array}$ \\
\hline $\begin{array}{l}\text { Hermes and } \\
\text { Lensink (2003) }\end{array}$ & $\begin{array}{l}67 \text { developing } \\
\text { countries, 1970- } \\
1995\end{array}$ & $\begin{array}{l}\text { Positive }- \text { in } \\
\text { interaction with } \\
\text { financial sector } \\
\text { development }\end{array}$ & $\begin{array}{l}\text { Quality of banking sector } \\
\text { (interest rate margin) is } \\
\text { more important than its } \\
\text { quantity (volume). }\end{array}$ \\
\hline Iacovoiu (2013) & $\begin{array}{l}8 \text { CEE countries, } \\
\text { comparison } 2006 \\
\text { and } 2011\end{array}$ & $\begin{array}{l}\text { Positive - better } \\
\text { results when FDI } \\
\text { involves higher } \\
\text { level of local } \\
\text { resources }\end{array}$ & Longer time series needed \\
\hline $\begin{array}{l}\text { Jimborean and } \\
\text { Kelber ( 2011) }\end{array}$ & $\begin{array}{l}8 \text { CEE countries, } \\
\text { 1993-2010 }\end{array}$ & Neutral & $\begin{array}{l}\text { No differentiation between } \\
\text { Greenfield and M\&A, short } \\
\text { time period }\end{array}$ \\
\hline
\end{tabular}




\begin{tabular}{|c|c|c|c|}
\hline $\begin{array}{l}\text { Kornecki and } \\
\text { Raghavan } \\
(2010)\end{array}$ & 5 CEE countries & Positive & $\begin{array}{l}\text { Aggregate data, small } \\
\text { (Slovenia) and big (Poland) } \\
\text { countries in the same } \\
\text { sample. }\end{array}$ \\
\hline $\begin{array}{l}\text { Lyroudi et al. } \\
(2004)\end{array}$ & $\begin{array}{l}18 \text { transitional } \\
\text { countries, 1995- } \\
1998\end{array}$ & Neutral & Too short time period. \\
\hline $\begin{array}{l}\text { Mehic et al. } \\
\text { (2013) }\end{array}$ & $\begin{array}{l}\text { 7 SEE countries, } \\
\text { 1998-2007 }\end{array}$ & Positive & $\begin{array}{l}\text { Short time period, no } \\
\text { differentiation between } \\
\text { Greenfield and M\& }\end{array}$ \\
\hline $\begin{array}{l}\text { Mencinger } \\
(2003)\end{array}$ & $8 \mathrm{CEE}$ countries & Negative & $\begin{array}{l}\text { No differentiation between } \\
\text { Greenfield and M\&A, short } \\
\text { time period }\end{array}$ \\
\hline Nanda (2009) & $\begin{array}{l}83 \text { countries, } \\
2001-2005\end{array}$ & $\begin{array}{l}\text { Positive - greenfield } \\
\text { Negative - M\&A }\end{array}$ & $\begin{array}{l}\text { Too big and heterogeneous } \\
\text { sample of countries. Very } \\
\text { short time period. }\end{array}$ \\
\hline $\begin{array}{l}\text { Neto et al. } \\
(2008)\end{array}$ & $\begin{array}{l}53 \text { countries split in } \\
\text { developed and } \\
\text { developing, 1996- } \\
2006\end{array}$ & $\begin{array}{l}\text { Positive - total FDI } \\
\text { Positive - } \\
\text { Greenfield } \\
\text { Negative - M\&A }\end{array}$ & $\begin{array}{l}\text { Short time period, no } \\
\text { differentiation between } \\
\text { short- and long-term effects }\end{array}$ \\
\hline $\begin{array}{l}\text { Nor Hakimah } \\
\text { Haji Mohd Not } \\
\text { et al. (2013) }\end{array}$ & $\begin{array}{l}\text { Sample of } \\
\text { developed and } \\
\text { developing } \\
\text { countries, 1998- } \\
2009\end{array}$ & $\begin{array}{l}\text { Positive - } \\
\text { developing } \\
\text { Negative - } \\
\text { developed (positive } \\
\text { in interaction with } \\
\text { quality of banking } \\
\text { sector) }\end{array}$ & $\begin{array}{l}\text { Interaction of banking } \\
\text { sector quality with } \\
\text { Greenfield and M\&A. }\end{array}$ \\
\hline $\begin{array}{l}\text { Savic et al. } \\
(2013)\end{array}$ & $\begin{array}{l}14 \text { CEE countries, } \\
2005-2010\end{array}$ & Positive & $\begin{array}{l}\text { Too short time period, no } \\
\text { time leg and difference } \\
\text { between short and long term } \\
\text { effects. }\end{array}$ \\
\hline $\begin{array}{l}\text { Toulaboe et al. } \\
(2009)\end{array}$ & $\begin{array}{l}\text { Developing } \\
\text { countries divided in } \\
\text { two group (with } \\
\text { higher and lower } \\
\text { GDP per capita), } \\
\text { 1978-2004 }\end{array}$ & $\begin{array}{l}\text { Positive- both } \\
\text { groups } \\
\text { Indirect effects } \\
\text { (interaction of FDI } \\
\text { with human capital) } \\
\text { stronger at } \\
\text { countries with } \\
\text { higher income }\end{array}$ & $\begin{array}{l}\text { No differentiation between } \\
\text { Greenfield and M\&A, } \\
\text { instead of secondary } \\
\text { education (human capital } \\
\text { proxy) use high education, } \\
\text { no time lag, no difference on } \\
\text { short and long term effects } \\
\text { on host country. }\end{array}$ \\
\hline $\begin{array}{l}\text { Wang and } \\
\text { Wong (2009) }\end{array}$ & $\begin{array}{l}84 \text { countries, } 1987- \\
2001\end{array}$ & $\begin{array}{l}\text { Positive - } \\
\text { Greenfield }\end{array}$ & $\begin{array}{l}\text { Too big sample. Smaller } \\
\text { homogeneous sample would } \\
\text { give more reliable results. }\end{array}$ \\
\hline
\end{tabular}




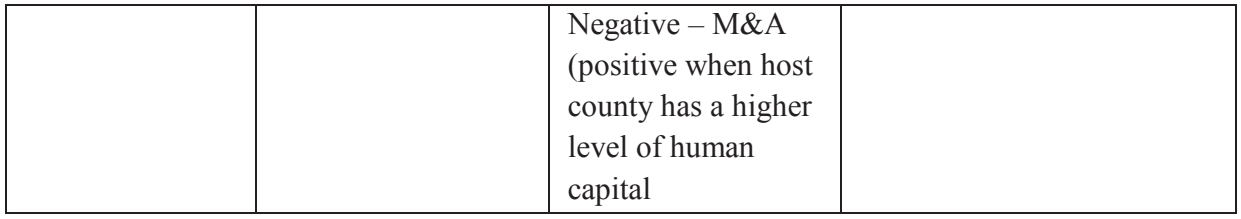

Source: As stated in the table.

Final conclusion after reviewing empirical studies how FDI affects economic growth on bulk sample of countries is that there is no consensus in regards to this question. Although majority of studies find positive influence, there are studies with neutral and negative results. Potential reasons for such findings may result from: too short time series, no time lags between FDI entrance and economic growth, heterogeneous sample and no differentiation between greenfield and M\&A investments. Namely, these two forms of investment are potentially different in nature and therefore not perfect substitutes for each other. Mencinger (2003) presumed that the entry mode might be a factor that explains the negative relationship between FDI and economic growth.

Table 2. Researches on FDI influence on Economic Growth - Individual sample

\begin{tabular}{|l|l|l|l|}
\hline \multicolumn{1}{|c|}{ Sources } & \multicolumn{1}{|c|}{ Data span } & \multicolumn{1}{c|}{$\begin{array}{c}\text { Effects of FDI on } \\
\text { EG }\end{array}$} & \multicolumn{1}{|c|}{$\begin{array}{c}\text { Weaknesses and } \\
\text { shortcomings }\end{array}$} \\
\hline $\begin{array}{l}\text { Abdulrahman } \\
\text { and Aga (2014) }\end{array}$ & $\begin{array}{l}\text { Turkey, 1980- } \\
2012\end{array}$ & $\begin{array}{l}\text { Positive - short } \\
\text { term }\end{array}$ & $\begin{array}{l}\text { No long term effects, no } \\
\text { differentiation of FDI }\end{array}$ \\
\hline Antwi (2013) & Ghana, 1980-2010 & Positive & Aggregate FDI \\
\hline Arisoy (2012) & $\begin{array}{l}\text { Turkey, 1960- } \\
2005\end{array}$ & Positive & Aggregate FDI \\
\hline $\begin{array}{l}\text { Dzambaska } \\
(2013)\end{array}$ & $\begin{array}{l}\text { FYR Macedonia, } \\
20005-2011\end{array}$ & Neutral & $\begin{array}{l}\text { Too short period, no time } \\
\text { lag }\end{array}$ \\
\hline $\begin{array}{l}\text { Geijer (2008) } \\
\text { Mexico, 1993- }\end{array}$ & Neutral & $\begin{array}{l}\text { Aggregate FDI, no } \\
\text { difference between short } \\
\text { and long term influence }\end{array}$ \\
\hline $\begin{array}{l}\text { Hassen and Anis } \\
(2012)\end{array}$ & Tunis, 1975-2009 & Positive & Aggregate FDI \\
\hline $\begin{array}{l}\text { Khaliq and Noy } \\
(2007)\end{array}$ & $\begin{array}{l}\text { Indonesia, 1997- } \\
2006\end{array}$ & Positive & Aggregate FDI, no time lag \\
\hline $\begin{array}{l}\text { Krstevska and } \\
\text { Petrovska (2012) }\end{array}$ & $\begin{array}{l}\text { FYR Macedonia, } \\
2001-2007\end{array}$ & Positive & $\begin{array}{l}\text { Too short period, no time } \\
\text { lag, no differentiation of } \\
\text { FDI }\end{array}$ \\
\hline $\begin{array}{l}\text { Leitao and } \\
\text { Rasekhi (2013) }\end{array}$ & $\begin{array}{l}\text { Portugal, 1995- } \\
2008\end{array}$ & $\begin{array}{l}\text { Positive - but } \\
\text { insignificant }\end{array}$ & $\begin{array}{l}\text { No difference between } \\
\text { greenfield and M\&A }\end{array}$ \\
\hline
\end{tabular}




\begin{tabular}{|l|l|l|l|}
\hline Massoud (2008) & Egypt, 1974-2005 & $\begin{array}{l}\text { Neutral - aggregate } \\
\text { Fositive - FDI in } \\
\text { secondary sector }\end{array}$ & $\begin{array}{l}\text { No differentiation between } \\
\text { greenfield and M\&A }\end{array}$ \\
\hline Mistzal (2010) & $\begin{array}{l}\text { Romania, 2000- } \\
2009\end{array}$ & Positive & $\begin{array}{l}\text { Aggregate FDI, short } \\
\text { period, no time lag and long } \\
\text { term effects }\end{array}$ \\
\hline Mun et al. (2008) & $\begin{array}{l}\text { Malaysia, 1970- } \\
2005\end{array}$ & Positive & $\begin{array}{l}\text { Aggregate FDI - no } \\
\text { differentiation between } \\
\text { greenfield and M\&A }\end{array}$ \\
\hline $\begin{array}{l}\text { Nkechi and } \\
\text { Okezie (2013) }\end{array}$ & $\begin{array}{l}\text { Nigeria, 1975- } \\
2008\end{array}$ & Negative & \begin{tabular}{l} 
Aggregate FDI \\
\hline Sen (2011)
\end{tabular} India, 1970-2008 \\
\hline Sisek (2005) & Croatia 1993-2004 & Neutral & $\begin{array}{l}\text { No analysis of FDI } \\
\text { influence on other sectors }\end{array}$ \\
\hline $\begin{array}{l}\text { Šohinger, } \\
\text { Galinec and } \\
\text { Skudar (2007) }\end{array}$ & $\begin{array}{l}\text { Croatia, 1998- } \\
\text { 2002 }\end{array}$ & Neutral & $\begin{array}{l}\text { Aggregate FDI, no } \\
\text { econometric model }\end{array}$ \\
\hline $\begin{array}{l}\text { lag short period, no time } \\
\text { between greenfield and } \\
\text { M\&A, no econometric } \\
\text { model }\end{array}$ \\
\hline
\end{tabular}

\section{Source: As stated in the table.}

Empirical researches based on individual country sample have also resulted with heterogeneous findings. Main objection is that studies are done on aggregate FDI data without differentiation between greenfield and M\&A investments.

After reviewing the relevant empirical studies, and aiming to dismantle the questions of the FDI impact on economic growth, four main potential reasons for these ambiguities have arisen:

1. One of the most important reasons for ambiguous results can be the use of total FDI flows and the lack of differentiation between two fundamentally different ways of entering the host economy, i.e. greenfield investment and mergers and acquisition (M\&A). Since these two types of investment have different characteristics and motives it is, therefore hard to believe they influence economic growth in the same way. Greenfield investment means setting up a new company or a plant in the host country with an almost immediate effect on the increased capital stock, newly created jobs. However, according to some analyses it can take up to five years for such an investment to show its full potential in contributing to the local economic growth (Brada and Tomsik, 2003; Altzinger, 2008). M\&A means transfer of ownership of the 
existing local company to foreign investor, often linked to some unpopular measures, such as restructuring, usually followed with inevitable layoffs (eg. privatization projects). These investments however need less time to realize their full profitability (as estimated up to three years). When company is profitable this is more beneficial for the local community (new jobs, additional tax revenues, etc.). Only a few papers dealt with this problem and made the distinction between greenfield investment and mergers and acquisition, when estimating the growth aspects of the incoming foreign capital (Calderon et al., 2004; Wang and Wong, 2009; Harms and Méon, 2013). However, when doing so, they mostly focused on a short period of time (direct effects), thus leaving the long-term effects out of scope.

2. Further reasons for the observed heterogeneity of the results can be found in the lack of proper differentiation between short- and long-term effects, or micro- and macroeconomic aspects, as well as in abandoning specific effects arising from breaks in the time series (financial crisis, crisis of the Eurozone, etc.), or some institutional aspects to which economic reforms and privatization in eastern Europe belong. It is unrealistic to expect immediate effects of FDI on economic growth, but most researchers neglect this and try to measure the influence of FDI on economic growth without time legs. The papers which take into account the deferred effects of FDI usually do that without the proper explanation as to their choice of the analytical method and its theoretical justification. Since FDI makes possible the transfer of modern technology, effects of which are expected in a longer period of time, the long term effects should be included in the analysis of the impact of FDI on economic growth. Furthermore, when entering a new market, foreign company utilizes its ownership (monopolistic) advantages, which make it more productive than the local competitors. Although foreign companies try to protect their technology, it spreads across local companies (through imitation and fluctuation of key personal), which then became more efficient and productive. Such effects are visible to their full extent just after a certain period of time, following the inflow of foreign capital on local market.

3. Further, a bulk of research has been done on a too big and sometimes even heterogeneous sample of countries. Putting together developed and developing countries in an analytical model can result in an outcome which calls for further explanation and a deeper analysis. Thus, more reliable results are expected to come from the analysis of more homogeneous samples of countries or industries (according to the level of economic development, country size, affiliation to some economic integration, or the economic sectors which received foreign capital, etc.). 
4. Relatively short time series sometimes combined with statistical methods that do not fully take into account all the above stated specifies, can only partly add to better understanding of the reasons behind economic growth generated through FDI. Empirical analyses are often done on very short time series (less than 10 years), whereas for more reliable results which will take into account indirect effects of foreign investments on the FDI host economy, longer time series, yet with respect to specific time breaks, should be used.

\section{CONCLUSION}

Endogenous growth models recognised technology as a main contributor to the economic growth, while FDI theory suggest that company has to have ownership or monopolistic advantage in form of superior technology and knowledge to enter into the foreign market. FDI inflow brings capital, but more important is transfer of new technology, knowledge and skills which through spillover effects leak toward local companies making them more productive and competitive. Although theory indicates positive influence of FDI on economic growth, empirical researches do not confirm it in totally. In most cases findings are positive, but some works indicate neutral or even negative influence.

By reviewing empirical literature several potential reasons for such ambiguous results are identified. First, most of researches used aggregate FDI data without differentiation between two fundamentally different ways of entering the host economy, i.e. greenfield investment and mergers and acquisition (M\&A). Since these two types of investment have different characteristics and motives it is, therefore hard to believe they influence economic growth in the same way. Second, reason for observed heterogeneity of the results could lie in the lack of proper differentiation between short- and long-term effects, or micro- and macroeconomic aspects, as well as in abandoning specific effects arising from breaks in the time series (financial crisis, crisis o the Eurozone, etc.), or some institutional aspects to which economic reforms and privatization in eastern Europe belong. Third, a most of researches were done on a too big and sometimes even heterogeneous sample of countries. Taking together developed and developing countries can result in an outcome which calls for further explanation and a deeper analysis. Fourth, relatively short time series sometimes combined with statistical methods that do not fully take into account all the above stated specifies, can only partly add to better understanding of the reasons behind economic growth generated through FDI 
Taking all the above into consideration, the paper should contribute to better understanding of the potential impacts of foreign direct investment on economic growth, by accounting for the weaknesses and shortcomings identified in the previous empirical research. As such the research should produce results useful for policy makers in creating better and more efficient economic policy measures aimed at attracting more effective FDI.

\section{REFERENCES:}

1. Aga, A.A.K. (2014) The Impact of FDI on economic Growth: A Case Study of Turkey 1980-2012, International Journal of Economics and Finance; Vol. 6, No. 7; 2014, doi: 10.5539/ijef.v6n7p71.

2. Adewumi, S. (2006) The impact of FDI on growth in Developing countries: An African experience, Master's thesis, Jönköping International Business School, Jönköping University.

3. Aghion, P., Howitt, P. (1992) A model of Growth Through creative Destruction", Econometrica, 60(2), doi: 10.3386/w3223.

4. Agrawal, G., Khan, M.A. (2011) Impact of FDI on GDP: A comparative Study of China and India, International Journal of Business and Management, Vol. 6, No. 10, doi: 10.5539/ijbm.v6n10p71.

5. Alfaro, L. (2003) Foreign Direct Investment and Growth: Does the Sector Matter?, Harvard Business School, 2003.

6. Alfaro, L. et. al. (2009) FDI, productivity and financial development, The World Economy, Vol. 32, Issue 1, pp. 111-135, doi: 10.1111/j.14679701.2008.01159.x.

7. Altzinger, W. (2008) The profitability of Austrian Foreign Direct Investment Reinvestment or Repatriation?, FIW Research Report, N 010, June 2008.

8. Antwi, S. et. al. (2013) Impact of foreign direct investment on economic growth: Empirical evidence from Ghana, International Journal of Academic Research in Accounting, Finance and Management Sciences, Vol 3, No. 1. January 2013, pp. $18-25$.

9. Apergis, N., Lyroudi, K., Vamvakidis, A: (2008) The relationship between FDI and economic growth: evidence from transitional countries, Transition Studies Review, 15, 37-51.

10. Arisoy, I. (2012) The Impact of foreign direct investment on total factor productivity and economic growth in Turkey, The journal of Developing Areas, Volume 46, No. 1, Spring 2012, doi: 10.1353/jda.2012.0013. 
11. Becker, G.S., Kevin M.M., Tamura R. (1990) Human Capital, Fertility, and Economic Growth, Journal of Political Economy, Vol. 98, No. 2.

12. Beugelsdijk, S. et. al. (2008) The impact of horizontal and vertical FDI on host's country economic growth, International Business Review 17 (2008), pp. 452472.

13. Borensztein, E., J. De Gregorio, and Lee, J.W. (1998) How Does Foreign Direct Investment Affect Economic Growth?, Journal of International Economics 45, pp. 115-135.

14. Brada J.C., Tomsik V. (2003) Reinvested Earnings Bias, the "Five Percent" Rule and the Interpretation of the Balance of Payments - with an Application to Transition Economies. University of Michigan Business School: William Davidson Institute Working Papers Series No. 543.

15. Brems, H. (1970) A growth model of international direct investment, American Economic Review 60.

16. Buckley, P.J. and Casson, M.C. (1976) The Future of the Multinational Enterprise, Homes \& Meier, London

17. Calderon, C., Loayza, N., Serven, L. (2004) Greenfield foreign direct investment and mergers and acquisitions. feedback and macroeconomic effects, World Bank Policy Research Working Paper 3192, January 2004.

18. Carkovic, M.V., Levine, R. (2002), Does Foreign Direct Investment Accelerate Economic Growth? University of Minnesota Department of Finance Working Paper.

19. Curwin, K.D., Mahutga, M.C. (2014) Foreign Direct Investment and Economic Growth: New Evidence from Post-Socialist Transition Countries, Social Forces 92(3), pp. 1159-1187, doi: 10.1093/sf/sot128.

20. Darrat, A.F. et al. (2005) FDI and economic growth in CEE and MENA countries: A tale of two regions, preliminary draft for possible presentation to the 12th, ERF's Annual Conference to be held in Cairo, Egypt, December 121, 2005, doi: 10.19030/iber.v4i12.3649.

21. Derado, D. (2013) Determinants of FDI in transition countries and estimation of the potential level of Croatian FDI, Financijska teorija i praksa, 37 (3), pp. 227258, doi: 10.3326/fintp.37.3.1.

22. Dunning, J. H. (1973) The determinants of international production, Oxford Economic Papers 25, pp. 289-336.

23. Dunning, J. H. (1980) Toward an eclectic theory of international production: Some empirical tests, Journal of International Business Studies issue 11. 
24. Dunning, J. H. (1988). The Eclectic Paradigm of International Production: A restatement and some possible extensions, Journal of International Business Studies issue 19.

25. Dzambaska, E. (2013) Empirical analysis of FDI and tax incentives on the economic growth in the Republic of Macedonia, Economic Development, Journal of the Institute of Economics-Skopje, Year 15, No. 3-2013, pp. 103-127.

26. Geijer, K. (2008) Foreign direct investment in Mexico: Possible effects on the Economic growth, Masters's thesis, Uppsala University, Department of Economics.

27. Grossman, G.M., Helpman, E. (1990) Trade, Innovation, and Growth, American Economic Review, Vol. 80, No. 2.

28. Harms, P., Méon, P-G. (2011) An FDI is an FDI is an FDI? The growth effects of Greenfield investment and mergers and acquisitions in developing countries, Proceedings of the German Development Economics Conference, Berlin 2011, No. 38.

29. Harms, P., Méon, P-G. (2013) The growth effects of greenfield investment and mergers and acquisitions: econometric investigation and implication for MENA countries, The Economic Research Forum (ERF), Working Paper No. 794.

30. Hassen, S., Anis, O. (2012.) Foreign Direct Investment and Economic Growth: An Approach in Terms of Cointegration for the Case of Tunisia, Journal of Applied Finance \& Banking, Vol. 2, No. 4, pp. 193-207.

31. Hayali, A.S. (2014) Is FDI beneficial for development in any case: an empirical comparison between greenfield and brownfield investments, Dogus Universitesi Dergisi, 15 (1), 15-30.

32. Helpman, E. (1992) Endogenous Macroeconomic Growth Theory, European Economic Review, 36(2/3), doi: 10.3386/w3869.

33. Hermes, N., Lensink, R. (2003) Foreign Direct Investment, Financial Development and Economic Growth, The Journal of Development Studies, vol. 40, No. 1, pp. 142-163.

34. Hymer, S. (1976 (1960 dissertation)) The International Operations of Nation Firms: A Study of Foreign Direct Investment, Cambridge, MLT Press.

35. Iacovoiu, V.B. (2013) Can FDI sustain CEE countries economic growth and development?, International Journal of Academic Research in Business and Social Sciences, August 2013, Vol. 3, No. 8, doi: 10.6007/IJARBSS/v3-i8/179.

36. Jimborean, R., Kelber, A. (2011) Foreign direct investment drivers and growth in Central and Eastern Europe in the immediate aftermath of the global financial and economic crisis, Working paper presented at 2011 Paris June Multilateral 
Seminar on „Financing of the economy in European Countries in the catching up phase"

37. Jones, L.E., Manuelli, R.E. (1990) A Convex Model of Equilibrium Growth: Theory and Policy Implications, Journal of Political Economy, 2. part, 98(5), doi: 10.1086/261717.

38. Julius, DA. (1991) Foreign Direct Investment: The Neglected Twin of Trade, Group of Thirty: Washington, DC.

39. Khaliq, A., Noy, I. (2007) Foreign direct investment and economic growth: empirical evidence from sectorial data in Indonesia, Working Papers No. 200726, University

40. Kindleberger C.P. (1969) American Business Abroad, Thundebird International Business Review, John Wiley and Sons, doi: 10.1002/tie.5060110207.

41. King, R.G., Rebelo, S., (1990) Public Policy and Economic Growth: Developing Neoclassical Implications, Journal of Political Economy, University of Chicago Press, Vol. 98(5), pp. 126-150.

42. King, R.G., Rebelo, S. (1993) Transitional Dynamics and Economic Growth in the Neoclassical Model, American Economic Review, 83(4), doi: 10.3386/w3185

43. Knickerbocker, F.T. (1973). Oligopolistic Reaction and the Multinational Enterprise, Harvard University Press, Cambridge.

44. Kornecki, L., Raghavan, V. (2011) Inward FDI stock and growth in Central and Eastern Europe, The International Trade Journal, Volume 25, n. 5, NovemberDecember 2011, doi: 10.1080/08853908.2011.604297.

45. Krstevska, A., Petrovska, M. (2012) The economic impacts of the foreign direct investments: panel estimation by sectors in the case of Macedonian economy, Journal of Central Banking Theory and Practice, 2012, 2, pp. 55-73.

46. Leitao, N.C., Rasekhi, S. (2013) The impact of foreign direct investment on economic growth: the Portugal experience, Theoretical and Applied Economics, volume XX, No. 18578), pp. 51-62.

47. Lucas, Jr., R.E. (1993) Making a Miracle, Econometrica, 60(2).

48. Lyroudi, K. et. al. (2004) Foreign direct investment and economic growth in transition economies, South Eastern Europe Journal of Economics 1 (2004) 97110.

49. Massoud, N. (2008) FDI and Growth in Emerging Markets: Does the Sectorial Distribution Matter - The Case of Egypt, EMG Working Paper Series WPEMG-05-2008, Cass Business School, London 
50. Mehic, E., Silajdzic, S., Babic-Hodovic, V. /2013) The impact of FDI on economic growth: some evidence from Southeast Europe, Emerging Markets Finance \& Trade / January-February 2013, Vol. 49, supplement 1 pp. 5-20.

51. Mencinger, J. (2003) Does FDI always enhance economic growth?, Kyklos, Vol. 56, Issue 4, pp. 491-508, doi: 10.1046/j.0023-5962.2003.00235.x.

52. Misztal, P. (2010) Foreign direct investments as a factor for economic growth in Romania, Journal of Advanced Studies in Finance, Volume I, Issue 1(1).

53. Mun, H.W. et. al. (2008) FDI and economic growth relationship: An empirical study on Malaysia, International Business Research, Vol. 1, No. 2, April 2008.

54. Nayak D., Choudhury R. (2014) A selective review of foreign direct investment theories, Asia-Pacific research and training network on trade, Working paper n. 143 .

55. Nanda, N. (2009) Growth effects of FDI: Is greenfield greener?, Perspectives on global development and technology, PGDT 8(2009) 26-47, doi: 10.1163/156914909x403171.

56. Neto, P., Brandao, A., Cerqueira, A. (2008) The impact of FDI, cross-border mergers and Acquisitions and greenfield investments on economic growth, Journal of Political Economy, 97(5), str.1003-1026.

57. Neuhaus, M. (2006), The Impact of FDI on Economic Growth: An Analysis for the Transition Countries of Central and Eastern Europe, Physica-Verlag, Heidelberg.

58. Nkechi, O.A., Okezie, O.K. (2013) Investigating the interaction between foreign direct investment and human capital on growth: evidence from Nigeria, Asian Economic and Financial Review, 2013, 3(9):1134-1151.

59. Nor, N.H.H.M. (2013) FDI and Economic Growth - Does the Quality of Banking Development Matter?, Gadjah Mada International Journal of Business, Vol. 15, No. 3, pp. 287-303.

60. Romer, P.M. (1986) Increasing Returns and Long-Run Growth, Journal of Political Economy, 94(5), doi: 10.1086/261420.

61. Romer, P.M. (1990) Endogenous Technological Change, Journal of Political Economy, 2, doi: 10.3386/w3210.

62. Savic, N., Barjaktarovic, L., Konjikusic, S. (2013) Impact of foreign capital inflow on GDPpc in CEE countries, International Journal of Engineering, tome XI - FASCICULE 4, Faculty of Engineering - Hunedoara, Romania.

63. Scott, M. (1991) A New View of Economic Growth - Four Lectures, World Bank Discussion Papers, br. 131, Washington, D.C.: The World Bank.

64. Sen, C. (2011) FDI in the Service Sector - Propagator of Growth for India?, MPRA Paper No. 30574. 
65. Sisek, B. (2005) FDI in Croatia - Causes of failure, Zbornik Ekonomskog fakulteta u Zagrebu, godina 3, 2005.

66. Solow, R.M. (1956) A Contribution to the Theory of Economic Growth, Quarterly Journal of Economics, 70(1), str. 312-361, doi: 10.2307/1884513.

67. Solow, R.M. (1957) Technical Change and the Aggregate Production Function, Review of Economics and Statistics, 39(3).

68. Šohinger, J., Galinec, D., Škudar; A. (2007) The Structure of FDI in Croatia and Its Impact on the Domestic Economy: An Empirical Analysis, Economic Integration: Prospects and Dilemmas, Faculty of Economics, University of Ljubljana, pp. 205-223.

69. Toulaboe, D., Terry, R., Johansen, T. (2009) Foreign direct investment and economic growth in developing countries, Southwestern economic Review, Vol. 36. No. 1.

70. UNCTAD (2019) World Investment Report 2019, United Nations, New York, Geneva.

71. Wang, M., Wong, M.C.S., (2009) What Drives Economic Growth? The Case of Cross-Border M\&A ad Greenfield FDI Activities, Kyklos 62:2, 316-330, doi: 10.1111/j.1467-6435.2009.00438.x. 


\section{IZRAVNA STRANA ULAGANJA I GOSPODARSKI RAST: ANALIZA TEKUĆEG STANJA EMPIRIJSKIH ISTRAŽIVANJA}

\section{Darko Horvatin}

\section{Sažetak}

Analizom teorija inozemnih direktnih ulaganja (FDI) $s$ neoklasičnim $i$ endogenim teorijama gospodarskog rasta, FDI je identificiran kao faktor koji izravno (akumulacija kapitala) i neizravno (prijenos tehnologije) pozitivno utječe na gospodarski rast. Međutim, empirijski rezultati vezani uz to pitanje vrlo su različiti. Stoga je svrha ovog rada kritički sagledati trenutačno stanje empirijskih istraživanja vezanih uz utjecaj inozemnih direktnih ulaganja na gospodarski rast zemlje primatelja kapitala. Pritom će ovo istraživanje uzeti u obzir ukupan svjetski priljev FDI-a od 1970. do danas. Generalni je zaključak da ne postoji jednoglasan stav o utjecaju FDI-a na gospodarski rast zemlje primateljice kapitala zbog različitih razloga koji se ponekad ne primjenjuju ispravno u empirijskim analitičkim modelima. Preciznije, taj utjecaj varira od vrlo pozitivnog do neutralnog, u najboljem slučaju ili čak negativnog. Razlozi takvih dvosmislenih nalaza proizlaze iz analitičkih slabosti (način kreiranja analitičkih uzoraka) i nedostatka boljeg razumijevanja teorijskih $i$ empirijskih aspekata doprinosa inozemnog kapitala gospodarskom rastu zemlje primateljice kapitala (ne razlikuju se kratkoročni i dugoročni učinci).

Ključne riječi: FDI, gospodarski rast, greenfield investicije, spajanja $i$ preuzimanja. 